\title{
THE HOFF EQUATIONS ON A GRAPH WITH THE MULTIPOINT INITIAL-FINAL VALUE CONDITION
}

S. A. Zagrebina ${ }^{1}$, zagrebinasa@susu.ru,

E. A. Soldatova ${ }^{1}$, soldatovaea@susu.ru

${ }^{1}$ South Ural State University, Chelyabinsk, Russian Federation

We consider the Hoff equations on a graph. For these equations, we prove the unique solvability of the multipoint initial-final value problem, and construct an analytical solution. As an example, we consider the Hoff equations on a double-edge graph with a three-point initial-final value condition. The article, in addition to the introduction and bibliography, contains two parts. The first part presents theoretical information about Sobolev type equations, as well as construction of a solution to an abstract Sobolev type equation with the multipoint initial-final value condition. In the second part, we apply the obtained abstract results to a specific Hoff model.

Keywords: Sobolev type equations; relatively bounded operator; multipoint initial-final value condition; Hoff model on a graph.

\section{Introduction}

Let $\mathbf{G}=\mathbf{G}(\mathfrak{V}, \mathfrak{E})$ be a finite connected oriented graph [1], where $\mathfrak{V}=\left\{V_{i}\right\}$ is the set of vertices, and $\mathfrak{E}=\left\{E_{i}\right\}$ is the set of edges such that each edge $E_{j}$ has length $l_{j} \in \mathbb{R}_{+}$ and cross-sectional area $d_{j} \in \mathbb{R}_{+}$. At vertices $\mathfrak{V}$ of the graph $\mathbf{G}$, define the conditions of "continuity" and "flow balance", respectively:

$$
\begin{gathered}
u_{j}(0, t)=u_{h}(0, t)=u_{m}\left(l_{m}, t\right)=u_{n}\left(l_{n}, t\right), \\
E_{j}, E_{h} \in E^{\alpha}\left(V_{k}\right), E_{m}, E_{n} \in E^{\omega}\left(V_{k}\right), \\
\sum_{j: E_{j} \in E^{\alpha}\left(V_{k}\right)} d_{j} u_{j x}(0, t)-\sum_{n: E_{n} \in E^{\omega}\left(V_{k}\right)} d_{n} u_{n x}\left(l_{n}, t\right)=0,
\end{gathered}
$$

where $E^{\alpha(\omega)}\left(V_{k}\right)$ is the set of edges that are incident to the vertex $V_{k}, t \in \mathbb{R}_{+}$. If the graph consists of the single non-cyclic edge (i.e., the graph has only two vertices), then condition (1) is absent, and condition (2) is equal to the Neumann condition. If the edge is cyclic (i.e., the graph has the single vertex), then conditions (1), (2) are equal to matched conditions. Also, note that in the context of conditions (1), (2), "to be absent" does not mean "to be zero". For example, if all edges are oriented such that the vertex $V_{k}$ is a "gutter" (i.e., there is no edge such that $V_{k}$ is a beginning of the edge), then the first two equalities in (1) and decreasing one in (2) are "absent", and are not zero.

On the graph $\mathbf{G}$ with conditions (1), (2), consider the linear Hoff model [2]

$$
\lambda_{j} u_{j t}+u_{j t x x}=\alpha_{j} u_{j}+f,
$$

which simulates the dynamics of buckling of I-beams in the structure under high temperature conditions. Here $u_{j}=u_{j}(x, t),(x, t) \in(a, b) \times \mathbb{R}_{+}$, characterizes the deviation 
of the $j$-th beam from the equilibrium position; the parameters $\lambda_{j} \in \mathbb{R}_{+}, \alpha_{j} \in \mathbb{R}$ characterize the material properties of this beam, $f_{j} \equiv f_{j}(x, t)$ corresponds to the external load on the $j$-th beam.

In the corresponding spaces, problem (1) - (3) is reduced to the linear Sobolev type equation $[3,4]$

$$
L \dot{u}=M u+f,
$$

for which we define the multipoint initial-final value condition [5]

$$
P_{0}\left(\eta(t)-\xi_{0}\right)=0, \quad P_{r}\left(\eta\left(\tau_{r}\right)-\xi_{r}\right)=0, \quad r=\overline{1, p},
$$

where $P_{r}$ are relatively spectral projectors, which we will define later; $\tau_{r} \in \mathbb{R},\left(\tau_{r-1}<\tau_{r}\right)$, $r=\overline{1, p}$. Let us give some explanations. Initial-final value problem (5) describes the following situation. Suppose that some object, for example, the structure of I-beams, moves in near-Earth space. At different times, only some projections of this object can be observed from the surface of the Earth. We want these projections to coincide with the given when observing. The mathematical model of this situation is defined by the Hoff equations given on a geometric graph and supplemented by an initial-final value condition.

Note that various questions for the Hoff equation in a bounded domain were studied by various researchers (see the reviews in $[6,7]$ ). On a graph, the Hoff equation was first investigated by G.A. Sviridyuk and V.V. Shemetova [8]. As a result, the simplicity of the phase space of the Cauchy problem for the Hoff equations on a graph is proved. The inverse problem for the Hoff equations on a graph was solved in [9]. Later, the paper [10] establishes the conditions of stability and asymptotic stability of the zero solution to the Cauchy problem of the Hoff equations on a graph. The optimal control of the solutions to the initial-final value problem for the Hoff equation was investigated in [3].

The goal of the paper is to prove the unique solvability of multipoint initial-final value problem (5) for problem (1) - (3).

\section{Generalized Splitting Theorem}

Let $\mathfrak{U}$ and $\mathfrak{F}$ be Banach spaces, the operators $L \in \mathcal{L}(\mathfrak{U} ; \mathfrak{F})$ (i.e., $L$ is linear and continuous) and $M \in \mathcal{C} l(\mathfrak{U}$; $\mathfrak{F})$ (i.e., $M$ is linear, closed, and densely defined). In addition, suppose that the operator $M$ is $(L, p)$-bounded, $p \in\{0\} \cup \mathbb{N}$ (see [11] for terminology and results), then there exist degenerate analytic groups of resolving operators

$$
U^{t}=\frac{1}{2 \pi i} \int_{\gamma} R_{\mu}^{L}(M) e^{\mu t} d \mu \quad \text { and } \quad F^{t}=\frac{1}{2 \pi i} \int_{\gamma} L_{\mu}^{L}(M) e^{\mu t} d \mu
$$

defined on the spaces $\mathfrak{U}$ and $\mathfrak{F}$, respectively. Moreover, $U^{0} \equiv P$ and $F^{0} \equiv Q$ are projectors. Here $\gamma$ is a contour bounding the domain $D$ containing the $L$-spectrum $\sigma^{L}(M)$ of the operator $M ; R_{\mu}^{L}(M)=(\mu L-M)^{-1} L$ is the right, and $L_{\mu}^{L}(M)=L(\mu L-M)^{-1}$ is the left $L$-resolvents of the operator $M$. For degenerate analytic group, the terms of the kernel $\operatorname{ker} U^{\cdot}=\operatorname{ker} P=\operatorname{ker} U^{t}$ for any $t \in \mathbb{R}$ and the image $\operatorname{im} U=\operatorname{im} P=\operatorname{im} U^{t}$ for any $t \in \mathbb{R}$ are correct. Let $\mathfrak{U}^{0}=\operatorname{ker} U, \mathfrak{U}^{1}=\operatorname{im} U$, and $\mathfrak{F}^{0}=\operatorname{ker} F \cdot \mathfrak{F}^{1}=\operatorname{im} F$, then $\mathfrak{U}^{0} \oplus \mathfrak{U}^{1}=\mathfrak{U}$ and $\mathfrak{F}^{0} \oplus \mathfrak{F}^{1}=\mathfrak{F}$. Denote by $L_{k}\left(M_{k}\right)$ the restriction of the operator $L(M)$ on $\mathfrak{U}^{k}\left(\operatorname{dom} M \cap \mathfrak{U}^{k}\right)$, $k=0,1$. 
Theorem 1. [11] (Splitting theorem). Let the operator $M$ be $(L, p)$-bounded, $p \in\{0\} \cup \mathbb{N}$. Then (i) the operators $L_{k} \in \mathcal{L}\left(\mathfrak{U}^{k} ; \mathfrak{F}^{k}\right), k=0,1$;

(ii) the operators $M_{0} \in \mathcal{C l}\left(\mathfrak{U}^{0} ; \mathfrak{F}^{0}\right), M_{1} \in \mathcal{L}\left(\mathfrak{U}^{1} ; \mathfrak{F}^{1}\right)$;

(iii) there exist the operators $L_{1}^{-1} \in \mathcal{L}\left(\mathfrak{F}^{1} ; \mathfrak{U}^{1}\right)$ and $M_{0}^{-1} \in \mathcal{L}\left(\mathfrak{F}^{0} ; \mathfrak{U}^{0}\right)$.

Suppose that $H=M_{0}^{-1} L_{0} \in \mathcal{L}\left(\mathfrak{U}^{0}\right), S=L_{1}^{-1} M_{1} \in \mathcal{L}\left(\mathfrak{U}^{1}\right)$. Consider the following condition:

$$
\left.\begin{array}{c}
\sigma^{L}(M)=\bigcup_{j=0}^{m} \sigma_{j}^{L}(M), m \in \mathbb{N}, \text { moreover, } \sigma_{j}^{L}(M) \neq \emptyset \text {, there exists } \\
\text { a closed countour } \gamma_{j} \subset \mathbb{C} \text { bounding the domain } D_{j} \supset \sigma_{j}^{L}(M) \\
\text { such that } \overline{D_{j}} \cap \sigma_{0}^{L}(M)=\emptyset, \overline{D_{k}} \cap \overline{D_{l}}=\emptyset \text { for all } j, k, l=\overline{1, m}, k \neq l .
\end{array}\right\}
$$

Then, the following theorem is correct.

Theorem 2. $[5,6]$ Suppose that the operator $M$ is $(L, p)$-bounded, $p \in\{0\} \cup \mathbb{N}$, and condition (A) holds. Then

(i) there exist the degenerate analytic groups

$$
U_{j}^{t}=\frac{1}{2 \pi i} \int_{\gamma_{j}} R_{\mu}^{L}(M) e^{\mu t} d \mu, j=\overline{1, m}
$$

(ii) $U^{t} U_{j}^{s}=U_{j}^{s} U^{t}=U_{j}^{s+t}$ for all $s, t \in \mathbb{R}, j=\overline{1, m}$;

(iii) $U_{k}^{t} U_{l}^{s}=U_{l}^{s} U_{k}^{t}=\mathbb{O}$ for all $s, t \in \mathbb{R}, k, l=\overline{1, m}, k \neq l$.

Suppose that $U_{0}^{t}=U^{t}-\sum_{k=1}^{m} U_{k}^{t}, t \in \mathbb{R}$.

Remark 1. Consider the units $P_{j} \equiv U_{j}^{0}, j=\overline{0, m}$, of the constructed (according to condition (A)) degenerate analytic groups $\left\{U_{j}^{t}: t \in \mathbb{R}\right\}, j=\overline{0, m}$. Obviously, $P P_{j}=P_{j} P=P_{j}, j=\overline{0, m}$, and $P_{k} P_{l}=P_{l} P_{k}=\mathbb{O}, k, l=\overline{0, m}, k \neq l$. By analogy, we can construct the projectors $Q_{j} \in \mathcal{L}(\mathfrak{F}), j=\overline{0, m}$, (see [9] for more details) such that $Q Q_{j}=Q_{j} Q=Q_{j}, j=\overline{0, m} ; Q_{k} Q_{l}=Q_{l} Q_{k}=\mathbb{O}, k, l=\overline{0, m}, k \neq l$.

The projectors $P_{j}, Q_{j}, j=\overline{0, m}$, are called relatively spectral projectors.

Consider the subspaces $\mathfrak{U}^{1 j}=\operatorname{im} P_{j}, \mathfrak{F}^{1 j}=\operatorname{im} Q_{j}, j=\overline{0, m}$. By construction,

$$
\mathfrak{U}^{1}=\bigoplus_{j=0}^{m} \mathfrak{U}^{1 j} \text { and } \mathfrak{F}^{1}=\bigoplus_{j=0}^{m} \mathfrak{F}^{1 j}
$$

Denote by $L_{1 j}$ the restriction of the operator $L$ on $\mathfrak{U}^{1 j}, j=\overline{0, m}$, and denote by $M_{1 j}$ the restriction of the operator $M$ on $\operatorname{dom} M \cap \mathfrak{U}^{1 j}, j=\overline{0, m}$. It is easy to see that $P_{j} \varphi \in \operatorname{dom} M$, if $\varphi \in \operatorname{dom} M$. Therefore, the domain dom $M_{1 j}=\operatorname{dom} M \cap \mathfrak{U}^{1 j}$ is dense in $\mathfrak{U}^{1 j}, j=\overline{0, m}$.

Theorem 3. $[5,6]$. (Generalized splitting theorem). Suppose that the operators $L \in \mathcal{L}(\mathfrak{U} ; \mathfrak{F})$ and $M \in \mathcal{C} l(\mathfrak{U} ; \mathfrak{F})$, and the operator $M$ is $(L, p)$-bounded, $p \in\{0\} \cup \mathbb{N}$, moreover, condition (A) holds. Then

(i) the operators $L_{1 j} \in \mathcal{L}\left(\mathfrak{U}^{1 j} ; \mathfrak{F}^{1 j}\right), M_{1 j} \in \mathcal{L}\left(\mathfrak{U}^{1 j} ; \mathfrak{F}^{1 j}\right), j=\overline{0, m}$;

(ii) there exist the operators $L_{1 j}^{-1} \in \mathcal{L}\left(\mathfrak{F}^{1 j} ; \mathfrak{U}^{1 j}\right), j=\overline{0, m}$. 
Suppose that condition (A) holds. Fix $\tau_{j} \in \mathbb{R},\left(\tau_{j}<\tau_{j+1}\right)$, the vectors $u_{j} \in \mathfrak{U}, j=\overline{0, m}$, and the vector-function $f \in C^{\infty}(\mathbb{R} ; \mathfrak{F})$. Consider the linear inhomogeneous Sobolev type equation

$$
L \dot{u}=M u+f .
$$

A vector-function $u \in C^{\infty}(\mathbb{R} ; \mathfrak{U})$ that satisfies equation (6) is called a solution to equation (6). A solution $u=u(t), t \in \mathbb{R}$, to equation (6) that satisfies the conditions

$$
P_{j}\left(u\left(\tau_{j}\right)-u_{j}\right)=0, \quad j=\overline{0, m},
$$

is called a solution to the multipoint initial-final value problem for equation (6).

Theorem 4. [9] Suppose that the operator $M$ is $(L, p)$-bounded, $p \in\{0\} \cup \mathbb{N}$, and condition (A) holds. Then for any $f \in C^{\infty}(\mathbb{R} ; \mathfrak{F}), u_{j} \in \mathfrak{U}, j=\overline{0, m}$, there exists the unique solution to problem (6), (7), moreover, the solution takes the form

$$
u(t)=-\sum_{q=0}^{p} H^{q} M_{0}^{-1}(\mathbb{I}-Q) f^{(q)}(t)+\sum_{j=0}^{m} U_{j}^{t-\tau_{j}} u_{j}+\sum_{j=0}^{m} \int_{\tau_{j}}^{t} U_{j}^{t-\tau_{j}-s} L_{1 j}^{-1} Q_{j} f(s) d s .
$$

\section{Linear Hoff Model on a Graph}

Remind that $\mathbf{G}=\mathbf{G}(\mathfrak{V}, \mathfrak{E})$ is a finite connected oriented graph, where $\mathfrak{V}=\left\{V_{k}\right\}$ is the set of vertices, and $\mathfrak{E}=\left\{E_{k}\right\}$ is the set of edges, moreover, each edge $E_{j}$ has length $l_{j} \in \mathbb{R}_{+}$and cross-sectional area $d_{j} \in \mathbb{R}_{+}$. At the vertices $\mathfrak{V}$ of the graph $\mathbf{G}$, define the conditions of "continuity"

$$
\begin{gathered}
u_{j}(0, t)=u_{h}(0, t)=u_{m}\left(l_{m}, t\right)=u_{n}\left(l_{n}, t\right), \\
E_{j}, E_{h} \in E^{\alpha}\left(V_{k}\right), E_{m}, E_{n} \in E^{\omega}\left(V_{k}\right),
\end{gathered}
$$

and "flow balance"

$$
\sum_{j: E_{j} \in E^{\alpha}\left(V_{k}\right)} d_{j} u_{j x}(0, t)-\sum_{n: E_{n} \in E^{\omega}\left(V_{k}\right)} d_{n} u_{n x}\left(l_{n}, t\right)=0
$$

where $E^{\alpha(\omega)}\left(V_{k}\right)$ is the set of edges that are incident to the vertex $V_{k}, t \in \mathbb{R}_{+}$. Supply conditions (9), (10) with the linear Hoff equations

$$
\lambda_{j} u_{j t}+u_{j t x x}=\alpha_{j} u_{j}+f .
$$

Consider problem (9) - (11). Based on the results of [3, 4], consider the Hilbert space $L_{2}(\mathbf{G})=\left\{g=\left(g_{1}, g_{2}, \ldots, g_{j}, \ldots\right): g_{j} \in L_{2}\left(0, l_{j}\right)\right\}$ with the scalar product

$$
\langle g, h\rangle=\sum_{E_{j} \in \mathfrak{E}} d_{j} \int_{0}^{l_{j}} g_{j} h_{j} d x
$$

and the Banach space $\mathfrak{U}=\left\{x=\left(u_{1}, u_{2}, \ldots, u_{j}, \ldots\right): u_{j} \in W_{2}^{1}\left(0, l_{j}\right)\right.$ and $(2)$ holds $\}$ with the norm

$$
\|u\|_{\mathfrak{U}}^{2}=\sum_{E_{j} \in \mathfrak{E}} d_{j} \int_{0}^{l_{j}}\left(u_{j x}^{2}+u_{j}^{2}\right) d x .
$$


According to the Sobolev embedding theorems, the functions that belongs to $W_{2}^{1}\left(0, l_{j}\right)$ are absolutely continuous. Therefore, the space $\mathfrak{U}$ is defined correctly.

Denote by $\mathfrak{F}$ the conjugate space to $\mathfrak{U}$ with respect to the duality $\langle\cdot, \cdot\rangle$. The formula

$$
\langle A u, v\rangle=\sum_{j} d_{j} \int_{0}^{l_{j}}\left(u_{j x} v_{j x}+b_{j} u_{j} v_{j}\right) d x, \quad u, v \in \mathfrak{U}
$$

defines the operator $A: \mathfrak{U} \rightarrow \mathfrak{F}$, where $b_{j} \in \mathbb{R}_{+}$are arbitrary constants. From the results of $[3,4]$, it follows that $A \in \mathcal{L}(\mathfrak{U} ; \mathfrak{F})$, moreover, the spectrum $\sigma(A)$ is positive, discrete, finite-multiple, and converges only to $+\infty$.

Construct the operators

$$
\begin{gathered}
\langle L u, v\rangle=\sum_{j} d_{j}\left(\lambda_{j}+b_{j}\right) \int_{0}^{l_{j}} u_{j} v_{j} d x-\langle A u, v\rangle, \\
\langle M u, v\rangle=\sum_{j} \alpha_{j} d_{j} \int_{0}^{l_{j}} u_{j} v_{j} d x .
\end{gathered}
$$

By construction, $L, M \in \mathcal{L}(\mathfrak{U} ; \mathfrak{F})$.

Lemma 4. $[3,4]$ For any $\alpha_{j} \neq 0, j \in \mathbb{N}$, such that $\alpha_{j}$ have the same sign, the operator $M$ is $(L, 0)$-bounded, and the relative spectrum $\sigma^{L}(M)$ of the operator $M$ is real, discrete, converges to 0 , and takes the form

$$
\sigma^{L}(M)=\left\{\mu_{i j}=\frac{\alpha_{j}}{\lambda_{j}-\nu_{i}}: i, j \in \mathbb{N} \backslash\left\{\lambda_{j}-\nu_{i}=0\right\}\right\}, \nu_{i} \in \sigma(A) .
$$

We are interested in the solutions to problem (9) - (11) satisfying multipoint initialfinal value conditions (5). The relative spectrum $\sigma^{L}(M)$ of the operator $M$ satisfies condition (A). Therefore, in (5), the projectors $P_{k}=\sum_{i: \mu_{i j} \in \sigma_{k}}\left\langle\cdot, \varphi_{i}\right\rangle \varphi_{i}, k=\overline{0, l}$, and $\varphi_{i}$ are the eigenfunctions of the operator $A$ that form a basis of the space $\mathfrak{U}$. Consequently, the multipoint initial-final value conditions (5) take the form

$$
\sum_{i: \mu_{i j} \in \sigma_{0}^{L}(M)}\left\langle\left(u(0)-u_{0}\right), \varphi_{i}\right\rangle \varphi_{i}=\sum_{i: \mu_{i j} \in \sigma_{k}^{L}(M)}\left\langle\left(u\left(\tau_{k}\right)-u_{k}\right), \varphi_{i}\right\rangle \varphi_{i}=0, \quad k=\overline{1, l},
$$

moreover,

$$
U_{k}^{t}=\sum_{i: \mu_{i j} \in \sigma_{k}^{L}(M)}{ }^{\prime} e^{\mu_{i j} t}\left(\cdot, \varphi_{i}\right) \varphi_{i}, \quad k=\overline{1, l}
$$

Similar to the scheme used in $[5,6]$, the following theorem is correct.

Theorem 7. For any $\alpha_{j} \neq 0, j \in \mathbb{N}$, such that $\alpha_{j}$ have the same sign, $\tau_{k} \geq 0$, $u_{k} \in \mathfrak{U}, k=\overline{0, l}$, multipoint initial-final value problem (9), (10), (14) for equation (11) has the unique solution $u \in C^{\infty}((a, b) ; \mathfrak{U})$, moreover, the solution takes the form

$$
u(t)=-\sum_{q=0}^{p}\left(M_{0}^{-1} L_{0}\right)^{q} M_{0}^{-1}(\mathbb{I}-Q) f^{(q)}(t)+\sum_{i=0}^{l} U_{i}^{t-\tau_{i}} u_{i}+\sum_{i=0}^{l} \int_{\tau_{i}}^{t} U_{i}^{t-s} L_{1 i}^{-1} Q_{i} f(s) d s .
$$




\section{Example 1.}

Let $\mathbf{G}_{\mathbf{1}}$ be a graph consisting of two edges that connect three vertices and have the common beginning, lengths $l_{1}$ and $l_{2}$, and cross-sectional areas $d_{1}=d_{2}=1$, see Fig. 1 .

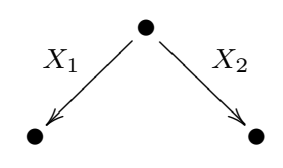

Fig. 1. Graph $\mathbf{G}_{\mathbf{1}}$

On the graph $\mathbf{G}_{\mathbf{1}}$, based on the results of [12], we have that the Sturm-Liouville problem

$$
\left\{\begin{array}{r}
X_{1} "+\lambda X_{1}=0 \\
X_{2} "+\lambda X_{2}=0 \\
X_{1}(0)=X_{2}(0) \\
X_{1}^{\prime}\left(l_{1}\right)=0 \\
x_{2}^{\prime}\left(l_{2}\right)=0 \\
X_{1}^{\prime}(0)+X_{2}^{\prime}(0)=0
\end{array}\right.
$$

has eigenvalues $\lambda_{k}=\left(\frac{\pi k}{l_{1}+l_{2}}\right)^{2}, k=\{0\} \cup \mathbb{N}$, which correspond to the following eigenfunctions:

$$
X^{k}(x)=\left(X_{1}^{k}(x), X_{2}^{k}(x)\right)=\left(C_{1} \cos \frac{\pi k}{l_{1}+l_{2}} x, C_{2} \cos \frac{\pi k}{l_{1}+l_{2}} x\right), k=\{0\} \cup \mathbb{N} .
$$

Moreover, taking into account the normalization condition, we have that

$$
C_{2}=\sqrt{\frac{2}{\left(l_{1}+l_{2}\right)\left(1+\operatorname{ctg}^{2} \frac{\pi k l_{1}}{l_{1}+l_{2}}+\frac{1}{\pi k} \operatorname{ctg} \frac{\pi k l_{1}}{l_{1}+l_{2}}+\frac{1}{2 \pi k} \sin \frac{2 \pi k l_{2}}{l_{1}+l_{2}}\left(\operatorname{ctg}^{2} \frac{\pi k l_{1}}{l_{1}+l_{2}}-3\right)\right)}},
$$

if $\sin \frac{\pi k l_{1}}{l_{1}+l_{2}} \neq 0$, and otherwise, i.e. for $\sin \frac{\pi k l_{1}}{l_{1}+l_{2}}=0$, we obtain that

$$
C_{1}=\sqrt{\frac{2}{l_{1}+l_{2}}}
$$

Therefore, if the edge lengths are $l_{1}=l_{2}=\pi$, then the eigenfunctions corresponding to the eigenvalues take the form

$$
\begin{gathered}
X^{0}(x)=\left(\sqrt{\frac{1}{\pi}}, \sqrt{\frac{1}{\pi}}\right), \quad \lambda^{0}=0, \\
X^{1}(x)=\left(\sqrt{\frac{1}{\pi}} \sin \frac{x}{2},-\sqrt{\frac{1}{\pi}} \sin \frac{x}{2}\right), \quad \lambda^{1}=\frac{1}{4}, \\
X^{2}(x)=\left(\sqrt{\frac{1}{\pi}} \cos x, \sqrt{\frac{1}{\pi}} \cos x\right), \quad \lambda^{2}=1,
\end{gathered}
$$




$$
\begin{aligned}
& X^{3}(x)=\left(\sqrt{\frac{1}{\pi}} \sin \frac{3 x}{2},-\sqrt{\frac{1}{\pi}} \sin \frac{3 x}{2}\right), \quad \lambda^{3}=\frac{9}{4}, \\
& X^{4}(x)=\left(\sqrt{\frac{1}{\pi}} \cos 2 x, \sqrt{\frac{1}{\pi}} \cos 2 x\right), \quad \lambda^{4}=5 .
\end{aligned}
$$

On the graph $\mathbf{G}_{\mathbf{1}}$, consider the linearized Hoff equations

$$
\lambda u_{j t}+u_{j t x x}=\alpha u_{j}, j=1,2
$$

with the conditions of "continuity" and "flow balance"

$$
\left\{\begin{array}{r}
u_{1}(0, t)=u_{2}(0, t) \\
u_{1 x}\left(l_{1}, t\right)=0 \\
u_{2 x}\left(l_{2}, t\right)=0 \\
u_{1 x}(0, t)+u_{2 x}(0, t)=0
\end{array}\right.
$$

Supply the problem with the three-point initial-final value condition

$$
\begin{gathered}
\sum_{i: \mu_{i} \in \sigma_{0}^{L}(M)}\left\langle\left(u(0)-u_{0}\right), \varphi_{i}\right\rangle \varphi_{i}=\sum_{i: \mu_{i} \in \sigma_{1}^{L}(M)}\left\langle\left(u\left(\tau_{1}\right)-u_{1}\right), \varphi_{i}\right\rangle \varphi_{i}= \\
=\sum_{i: \mu_{i} \in \sigma_{2}^{L}(M)}\left\langle\left(u\left(\tau_{2}\right)-u_{2}\right), \varphi_{i}\right\rangle \varphi_{i}=0
\end{gathered}
$$

where

$$
\begin{gathered}
\sigma_{0}^{L}(M)=\left\{\mu_{i}=\frac{\alpha}{\lambda-\lambda^{i}}: i>4\right\}, \\
\sigma_{1}^{L}(M)=\left\{\mu_{i}=\frac{\alpha}{\lambda-\lambda^{i}}: i=1,3\right\}=\left\{\frac{4 \alpha}{4 \lambda-1}, \frac{4 \alpha}{4 \lambda-9}\right\}, \\
\sigma_{2}^{L}(M)=\left\{\mu_{i}=\frac{\alpha}{\lambda-\lambda^{i}}: i=0,2,4\right\}=\left\{\frac{\alpha}{\lambda}, \frac{\alpha}{\lambda-1}, \frac{\alpha}{\lambda-4}\right\} .
\end{gathered}
$$

According to Theorem 1, the solution takes the form

$$
\begin{gathered}
u(t)=\sum_{\mu_{i} \in \sigma_{0}^{L}(M)} e^{\mu_{i}\left(t-\tau_{0}\right)}\left\langle u_{0}, \varphi_{i}\right\rangle_{L_{2}(\mathbf{G}) \varphi_{i}+} \\
+\sum_{\mu_{k} \in \sigma_{1}^{L}(M)} e^{\mu_{k}\left(t-\tau_{1}\right)}\left\langle u_{1}, \varphi_{i}\right\rangle_{L_{2}(\mathbf{G})} \varphi_{i}+\sum_{\mu_{i} \in \sigma_{2}^{L}(M)} e^{\mu_{i}\left(t-\tau_{2}\right)}\left\langle u_{2}, \varphi_{I}\right\rangle_{L_{2}(\mathbf{G})} \varphi_{i} .
\end{gathered}
$$

The work was supported by Act 211 Government of the Russian Federation, contract no. 02.A03.21.0011. 


\section{References}

1. Sviridyuk G.A. Sobolev Type Equations on Graphs. Nonclassical Equations of Mathematical Physics. Novosibirsk, IM CO RAN Publ., 2002, pp. 221-225. (in Russian)

2. Hoff N.J. Creep Buckling. Journal of the Aeronautical Sciences, 1956, no. 7, pp. 1-20.

3. Manakova N.A., Dyl'kov A.G. Optimal Control of the Solutions of the Initial-Finish Problem for the Linear Hoff Model. Mathematical Notes, 2013, vol. 94, no. 1-2, pp. 220-230. DOI: 10.1134/S0001434613070225.

4. Bayazitova A.A. On the Generalized Boundary-Value Problem for Linear Sobolev Type Equations on the Geometric Graph. Bulletin of the South Ural State University. Series: Mathematics. Mechanics. Physics, 2018, vol. 10, no. 3, pp. 5-11. (in Russian) DOI: $10.14529 / \mathrm{mmph} 180301$.

5. Favini A., Zagrebina S.A., Sviridyuk G.A. Multipoint Initial-Final Value Problems for Dynamical Sobolev-Type Equations in the Space of Noises. Electronic Journal of Differential Equations, 2018, vol. 2018, no. 128, pp. 1-10, available at: https://ejde.math.txstate.edu/Volumes/2018/128/favini.pdf (accessed on January 10, 2019).

6. Zagrebina S.A. The Multipoint Initial-Finish Problem for Hoff Linear Model. Bulletin of the South Ural State University. Series: Mathematical Modelling, Programming and Computer Software, 2012, no. 5 (264), pp. 4-12. (in Russian)

7. Sagadeeva M.A., Generalov A.V. Numerical Solution for Non-Stationary Linearized Hoff Equation Defined on Geometrical Graph. Journal of Computational and Engineering Mathematics, 2018, vol. 5, no. 3, pp. 61-74. DOI: 10.14529/jcem180306.

8. Sviridyuk G.A., Shemetova V.V. Hoff Equations on Graphs. Differential Equations, 2006, vol. 42, issue 1, pp. 139-145. DOI: 10.1134/S0012266106010125.

9. Sviridyuk G.A., Bayazitova A.A. On Direct and Inverse Problems for the Hoff Equations on Graph. The Journal of Samara State Technical University, Ser. Physical and Mathematical Sciences, 2009, issue 1 (18), pp. 6-17. (in Russian) DOI: $10.14498 /$ vsgtu670.

10. Sviridyuk G.A., Zagrebina S.A., Pivovarova P.O. Stability Hoff Equation on a Graph. The Journal of Samara State Technical University, Ser. Physical and Mathematical Sciences, 2010, issue 1 (20), pp. 6-15. (in Russian).

11. Sviridyuk G.A. On the General Theory of Operator Semigroups. Russian Mathematical Surveys, 1994, vol. 49, no. 4, pp.45-74.

12. Zamyshlyaeva A.A., Tsyplenkova O.N. [Sobolev Type Equations on a Graph]. Chelyabinsk, Publishing Centre of SUSU, 2016. (in Russian).

Sophiya A. Zagrebina, DSc (Physics and Mathematics), Head of the Department of Mathematical and Computer Modelling, South Ural State University (Chelyabinsk, Russian Federation), zagrebinasa@susu.ru. 
Ekaterina A. Soldatova, Senior Lecturer, Department of Mathematical and Computer Modelling, South Ural State University (Chelyabinsk, Russian Federation), soldatovaea@susu.ru.

Received January 10, 2019.

УДК 517.9

DOI: $10.14529 /$ jcem190205

\title{
УРАВНЕНИЯ ХОФФА НА ГРАФЕ С МНОГОТОЧЕЧНЫМ НАЧАЛЬНО-КОНЕЧНЫМ УСЛОВИЕМ
}

\author{
C. А. Загребина, E. А. Солдатова
}

\begin{abstract}
В статье рассматриваются уравнения Хоффа на графе. Для этих уравнений доказана однозначная разрешимость многоточечной начально-конечной задачи и построено аналитическое решение. В качестве примера рассмотрены уравнения Хоффа на двухреберном графе с трехточечным начально-конечным условием. Статья, кроме введения и списка литературы, содержит две части. В первой части приведены теоретические сведения об уравнениях соболевского типа, а также построено решение абстрактного уравнения соболевского типа с многоточечным начально-конечным условием. Во второй полученные абстрактные результаты применяются к конкретной модели Хоффа.

Ключевые слова: уравнения соболевского типа; относительно ограниченный оператор; многоточечное начально-конечное условие; модель Хоффа на графе.
\end{abstract}

\section{Литература}

1. Свиридюк, Г.А. Уравнения соболевского типа на графе / Г.А. Свиридюк Неклассические уравнения математической физики. - Новосибирск, 2002. C. $221-225$.

2. Hoff, N.J. Creep Buckling / N.J. Hoff // Journal of the Aeronautical Sciences. - 1956. № 7 . - P. 1-20.

3. Манакова, Н.А. Оптимальное управление решениями начально-конечной задачи для линейной модели Хоффа / Н.А. Манакова, А.Г. Дыльков // Математические заметки. - 2013. - Т. 94, № 2. - С. 225-236.

4. Баязитова, А.А. Об обобщенной краевой задаче для линейных уравнений соболевского типа на графе / А.А. Баязитова // Вестник ЮУрГУ. Серия: Математика. Механика. Физика. - 2018. - Т. 10, № 3. - С. 5-11.

5. Favini, A. Multipoint Initial-Final Value Problems for Dynamical Sobolev-Type Equations in the Space of Noises / A. Favini, S.A. Zagrebina, G.A. Sviridyuk // Electronic Journal of Differential Equations. - 2018. - V. 128. - P. 1-10. URL: https:/ /ejde.math.txstate.edu/Volumes/2018/128/favini.pdf (дата обращения: 10.01.2019).

6. Загребина, С.А. Многоточечная начально-конечная задача для линейной модели Хоффа / С.А. Загребина // Вестник ЮУрГУ. Серия: Математическое моделирование и программирование. - 2012. - № 5 (264), вып. 11. - С. 4-12. 
7. Sagadeeva, M.A. Numerical Solution for Non-Stationary Linearized Hoff Equation Defined on Geometrical Graph / M.A. Sagadeeva, A.V. Generalov // Journal of Computational and Engineering Mathematics. - 2018. - V. 5, № 3. - P. 61-74.

8. Свиридюк, Г.А. Уравнения Хоффа на графе / Г.А. Свиридюк, В.В. Шеметова // Дифференциальные уравнения. - 2006. - Т. 42, № 1. - С. 126-131.

9. Свиридюк, Г.А. О прямой и обратной задачах для уравнений Хоффа на графе / Г.А. Свиридюк, А.А. Баязитова // Вестник Самарского государственного технического университета. Серия: Физико-математические науки. - 2009. - № 1 (18). C. 6-17.

10. Свиридюк, Г.А. Устойчивость уравнений Хоффа на графе / Г.А. Свиридюк, С.А. Загребина, П.О. Пивоварова // Вестник Самарского государственного технического университета. Серия: Физико-математические науки. - 2010. № 1 (20). - C. 6-15.

11. Свиридюк, Г.А. К общей теории полугрупп / Г.А. Свиридюк // Успехи математических наук. - 1994. - Т. 49, № 4. - С. 47-74.

12. Замышляева, А.А. Уравнения соболевского типа на графах / А.А. Замышляева, О.Н. Цыпленкова. - Челябинск: Изд. центр ЮУрГУ, 2016.

Загребина Софъя Александровна, доктор физико-математических наук, заведующий кафедрой математического и компьютерного моделирования, ЮжноУральский государственный университет (г. Челябинск, Российская Федераиия), zagrebinasa@susu.ru.

Солдатова Екатерина Александровна, стариий преподаватель кафедры математического и компъютерного моделирования, Южно-Уральский государственный университет (г. Челябинск, Российская Федерация), soldatovaea@susu.ru.

Поступила в редакцию 10 января 2019 г. 